\title{
Relationships between temperature and latent periods of rust and leaf-spot diseases of groundnut
}

\author{
K. D. R. WADIA and D. R. BUTLER \\ Resource Management Program, International Crops Research Institute for the Semi-Arid'Tropics \\ (ICRISAT), Patancheru PO. Andhra Pradesh 502 324. India
}

The effect of temperature on the latent periods of rust, late leaf spot and early leaf spot diseases of groundnut caused by Puccinia arachidis, Phaeoisariopsis personata and Cercospora arachidicola, respectively, was studied. The latent periods (LP) of rust, late leaf spot and early leaf spot ranged from 12-49 days, 13-38 days and 13-39 days, respectively, between $12^{\circ} \mathrm{C}$ and $33 \mathrm{C}$. An equation relating the rate of pathogen development (1/LP) to temperature was fitted using daily mean temperatures to provide three cardinal temperatures: the minimum $\left(T_{\min }\right)$, optimum $\left(T_{\text {opt }}\right)$, and maximum $\left(T_{\max }\right) . T_{\min }$ was about $12^{\circ} \mathrm{C}$ for rust and about $10^{\circ} \mathrm{C}$ for the two leaf-spot diseases. $T_{\text {opt }}$ for all three diseases was close to $25^{\circ} \mathrm{C}$. $T_{\max }$ was $31^{\circ} \mathrm{C}$ for early leaf spot, and extrapolated values for late leaf spot and rust were about 35 and $40^{\circ} \mathrm{C}$, respectively.

For $\boldsymbol{P}$. personata, a temperature response curve was fitted using data only from controlled environment experiments. This curve was used to simulate latent periods from both mean daily and mean hourly temperatures in the field. There was substantially better agreement between observed and simulated latent period with hourly temperatures, provided the developmental rate of the pathogen was determined at a constant temperature.

\section{INTRODUCTION}

Rust caused by Puccinia arachidis, late leaf spot caused by Phaeoisariopsis personata, and early leaf spot caused by Cercospora arachidicola are of great economic importance to groundnut (Arachis hypogaea) wherever it is grown (Subrahmanyam \& McDonald, 1983; McDonald et al., 1985; Bunting et al., 1985).

Current disease control strategies vary widely. In the USA the use of fungicides is common (Knudsen et al., 1987), whereas in tropical regions the use of chemicals is restricted and often no disease control measures are taken. Rational disease control should reduce the use of fungicide in developed countries and substantially increase yield in the tropics. ldeally, management strategies for groundnut foliar diseases should include resistant varieties with good agronomic characteristics. Recent progress in breeding has resulted in the release of some promising varieties with various degrees of resistance to rust and late leaf spot (Wynne et al., 1991). Smith (1980) pointed out the need for further studies on the epidemiology of groundnut foliar pathogens to develop disease management strategies. An understand- ing of the relationships between groundnut plants, the pathogens and their environment is fundamental to improvements in disease control.

Latent period (L.P) is the number of days between inoculation and the time lesions start to sporulate. Within a population of lesions, individuals start sporulating at different times so it is possible to define the latent period in various ways. In a study on Puccinia recondita on wheat, Tomerlin et al. (1983) compared periods terminating with the appearance of the first uredinium. the appearance of $50 \%$ of uredinia and the appearance of the last uredinium. They found no difference in the ranking of cultivar-temperature treatments, so they used the time to $50 \%$ of uredinia appearance to describe the latent period. We are adopting an equivalent definition, also used by Johnson (1980) and Shaw (1986) that the latent period is the period from inoculation to the time when $50 \%$ of lesions are sporulating. The importance of the latent period to epidemiology has long been recognized (Zadoks, 1972), and it is a strong component of resistance (Nevill, 1980). There are a number of reports of the variability of latent period with genotype for groundnut foliar diseases (e.g., Foster ef al., 1980; Nevill, 198I: 
Johnson et al., 1986), but only a few studies have examined how temperature affects latent period. Savary (1985) reported how latent period varied for rust over a limited temperature range (18 to 28 C), but we could not find published reports of any similar studies on either $\boldsymbol{P}$. personata or C. arachidicola on groundnut.

There are a number of reports of the effect of temperature on latent period of other diseases, and a variety of mathematical equations have been used to describe the relationships. For barley brown rust, Teng et al. (1980) fitted a thirdorder polynomial equation to data relating latent period to temperature, whereas Beresford \& Royle (1988) examined a wider range of temperatures and demonstrated a hyperbolic relationship that gives a linear relationship between the reciprocal of latent period (1/LP) and temperature. Reports for other diseases have shown that the relationship between $\mathrm{I} / \mathrm{LP}$ and temperature becomes non-linear at high temperatures (e.g., Shaw, 1986, 1990).

In this paper the effect of temperature on the latent periods of $P$. arachidis, $P$. personata, and $C$. arachidicola on groundnut are analysed, and appropriate curves are fitted to the data with an analytical model. For $P$. personata the model is tested with both daily and hourly mean temperatures.

\section{MATERIALS AND METHODS}

The effect of temperature on the latent periods of rust, late leaf spot and early leaf spot was studied from December 1990 to March 1992.

\section{Plant material}

Experiments were carried out on the groundnut cultivar TMV 2 which is susceptible to rust and leaf spots. Plants were raised in 13-cm diameter plastic pots in a glasshouse. Coolers were operated in the glasshouse to prevent the air temperature exceeding $35 \mathrm{C}$, but minimum temperature and humidity depended largely on the external ambient conditions. The minimum temperature varied between $12 \mathrm{C}$ and $20 \mathrm{C}$, and the minimum humidity ranged from 30 to $50 \%$ during day and from 60 to $90 \%$ at night.

Four sceds were sown in each pot containing a potting medium of $50 \%$ loam, $25 \%$ sand and $25 \%$ compost. The medium was sterilized and no root nodulation was observed. Seedlings were later thinned to two healthy plants per pol and were fed with Broughton's nutrient solution (Brough- ton \& Dilworth, 1971) once every week. Healthy plants were maintained without the use of pesticides and insect damage was eliminated by removing affected plants. Four-week-old plants were used for inoculation experiments.

\section{Inoculum}

Inoculum was obtained by multiplying locally collected isolates of urediniospores (for rust) and conidia (for early and late leaf spot) on groundnut leaves (cv. TMV 2). Initially, for multiplication of inoculum, a spore suspension of approximately $50000 \mathrm{spores} / \mathrm{ml}$ was sprayed on potted plants. Plants were kept wet for $24 \mathrm{~h}$ (for rust) or for five consecutive nights of $16 \mathrm{~h}$ (for leaf spots) in a dew chamber (Clifford, 1973) to ensure good infection. After the lesions were fully developed, diseased leaves were excised and arranged with their petioles buried in sterilized wet river-sand in plastic trays and covered with a polythene bag. After incubation for 6-7 days in an incubator (Percival Co., Iowa, USA) at $23^{\circ} \mathrm{C}$ temperature to enhance sporulation, spores were harvested with a cyclone spore collector and stored in small glass vials at 4 C.

\section{Inoculation}

A spore suspension was prepared in distilled water with a few drops of Tween $\mathbf{8 0}$ (polyoxyethylene sorbitan mono-oleate) wetting agent. The spore concentration was determined with a haemocytometer and adjusted to 10000 spores $\mathrm{ml}$. This was sufficient to achieve typical lesion densities of 3-4 per $\mathrm{cm}^{2}$ The suspension was sprayed with a plastic atomizer, ensuring that both sides of the leaves were completely wetted. All the leaves on the main axis of the plant were inoculated and eight to 24 plants (four to 12 pots) were used for each temperature experiment.

As it has been demonstrated that liquid water is necessary for infection by rust (Malliah \& Rao. 1979; Cook, 1980) and long periods of leaf wetness enhance infection by leaf spot pathogens (Lannou \& Blizoua Bi, 1989; Butler, 1990), pots were kept in controlled temperature dew chambers to ensure complete wetting of leaves. The mean temperature during the infection period was accounted for in computing the werall treatment temperature. A continuous wetness period of $24 \mathrm{~h}$ was provided for rust. For leaf spot discases, plants were placed in the dew chambers for at least tive consecutive nights of $16 \mathrm{~h}$ and allowed to dry during the day so the total 
period of intermittent leaf wetness was $80 \mathrm{~h}$. Day/night temperatures were chosen to give daily means similar to those expected in the field at that time.

Between December 1990 and May 1991, plants were inoculated at weekly intervals and after providing wetness for infection, they were placed outside on the ICRISAT meteorological site, where air temperatures were monitored by an automatic weather station. The conditions on the site provided a limited range of mean temperatures ( 19 to $32 \mathrm{C}$ ), so additional inoculated plants were placed either in controlled environment growth cabinets (Conviron Model CG 1011, Winnipeg, Canada) or in a glasshouse. The photosynthetic photon flux density in the growth cabinets was about $450 \mu \mathrm{mol} / \mathrm{m}^{2}$.s and the mean irradiance in the glasshouse was about $60 \%$ of daylight. The growth cabinet temperatures were selected to obtain values that did not occur on the site, and to extend the temperature range. Additional values were obtained in the glasshouse, where temperature control was limited to the use of evaporative coolers. The mean temperature between the time of inoculation and the final latent period assessment was computed for each set of plants. A total of 51 sets of data were obtained for rust, 63 sets for late leaf spot and 50 sets for early leaf spot.

\section{Latent period assessment}

Seven days after inoculation the third, fourth and fifth leaves from the top of each plant were carefully examined each day for lesion appearance. These leaves were selected because leaves 1 and 2 emerged after inoculation and the total number of leaves on the main stem at the time of lesion appearance varied between 6 and 8 . For rust, numbers of uredinia per leaf were recorded when they appeared. Subsequently, the leaves were scanned with a stereomicroscope (for plants kept on the site, representative leaflets were excised and observation was made in the laboratory) and numbers of ruptured and unruptured uredinial sori were recorded. The day on which at least $50 \%$ of uredinial sori ruptured was taken as the end of the latent period. For early and late leaf spots, the number of lesions per leaf were recorded and the lesions were scanned with a stereomicroscope for sporulation (the adaxial leaf surfaces were examined for $C$. arachidicola and the abaxial leaf surfaces for $P$. personala). The end of the latent period was determined when at least $50 \%$ of lesions were sporulating. Lesions were considered to be sporulating when caespituli (swellings) were visible with a matt-like appearance. The caespituli may not have erupted to release conidia naturally at this stage, as their release is strongly affected by humidity, but conidia could be seen in scrapings. If there was any doubt about the presence of conidia, the plants were covered with a polythene bag for $24 \mathrm{~h}$ to promote their release. For both rust and leafspot diseases at least 24 leaves were used for the final assessment.

\section{Latent period at a constant temperature}

While analysing the results for late leaf spot, we found a requirement for the latent period determined at a constant temperature (the optimum value). We therefore carried out an additional experiment with both the dew chamber and plant growth cabinet set to $24 \mathrm{C}$ (the same temperature for day and night). After inoculation, 24 plants were placed in the dew chamber for five consecutive nights $(16 \mathrm{~h})$ and moved to the growth cabinet each day. After the first five nights they were left continuously in the growth cabinet with lights operating 8 h each day. On days 9 to 16 after inoculation, six leaves with 380 lesions were systematically scanned with a stereomicroscope twice a day (at 0800 and 1600 hours) for the appearance of caespituli. On each occasion six other leaflets with similar lesions were detached and placed on moist filter paper in petri dishes. The petri dishes were kept in the growth cabinet at $24 \mathrm{C}$ to confirm conidial release.

\section{RESULTS AND DISCUSSION}

The longest latent periods occurred at the lowest temperatures and the shortest periods occurred between $20 \mathrm{C}$ and $30 \mathrm{C}$ for all three discases (Fig. 1). The longest latent period was 49 days for rust (at $13 \mathrm{C}$ ). compared with $35-40$ days for the leaf spots (at about $1+\mathrm{C}$ ). The shortest latent period for rust was 12 days and for the leaf spots it was 13 days. For rust, latent periods increased slightly at temperatures above $30 \mathrm{C}$, and for the leaf spots the effect was more marked and occurred above $27 \mathrm{C}$.

The reciprocal of the latent period $(1 / L P)$ is a measure of the rate of pathogen development. By plotting 1/LP against temperature (Fig. 2), the

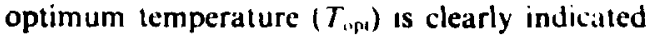
where the maximum rate of development (minimum latent period) occurs. Also in Fig. 2, the reduction in the rate of development at high temperatures is more noticable for rust than the 

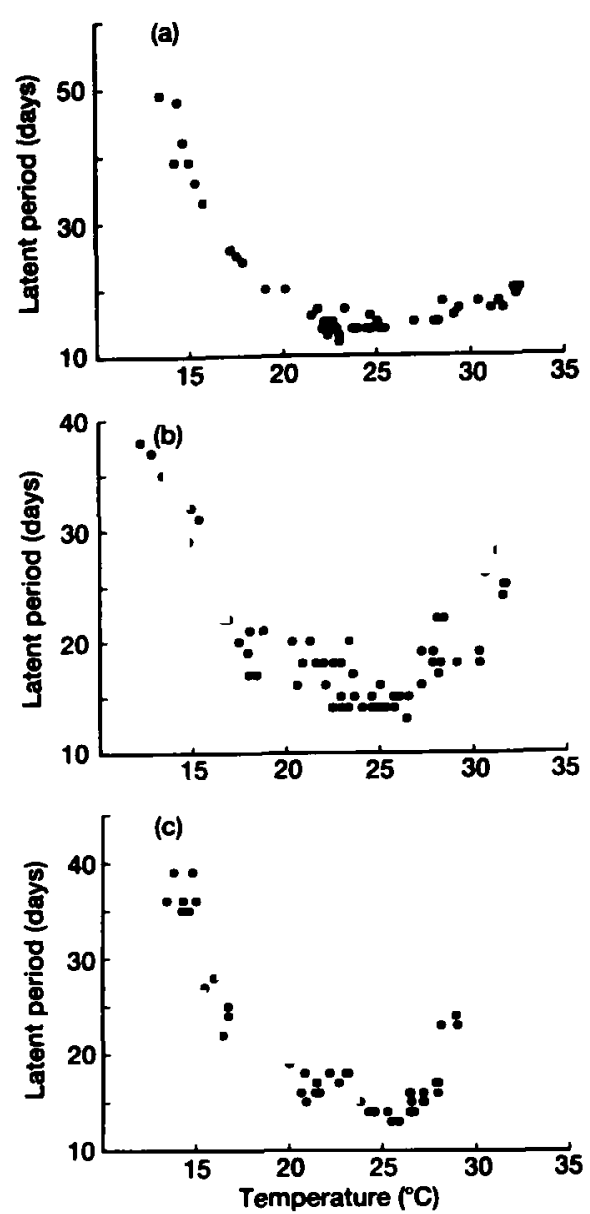

Fig. 1. Relationships between daily mean temperature and the latent periods of (a) Puccinia arachidis, (b) Phaeoisariopsis personata and (c) Cercospora arachidicola on groundnut.

slight increase in latent period in Fig. la. Temperature response curves have been fitted to the data in Fig. 2 which assume that there are minimum and maximum temperatures ( $T_{\min }$ and $T_{\max }$ ) at which development ceases (so $1 / \mathrm{LP}$ tends to zero). $T_{\min }$ and $T_{\max }$ can be thought of as the temperatures at which sporulation never occurs (an infinite latent period).

The temperature response curve with three cardinal temperatures (minimum, maximum and optimum) is defined in equation I (Reed et al., 1976):

$$
\begin{aligned}
1 / \mathrm{LP} & =\mathrm{a}\left(T-T_{\min }\right)\left(T_{\max }-T\right)^{\circ} \\
\text { where a } & =y_{\max } /\left(\left(T_{\text {opx }}-T_{\min }\right)\left(T_{\max }-T_{\text {opx }}\right)\right) \\
\beta & =\left(T_{\max }-T_{o p x}\right) /\left(T_{o p 1}-T_{\min }\right)
\end{aligned}
$$
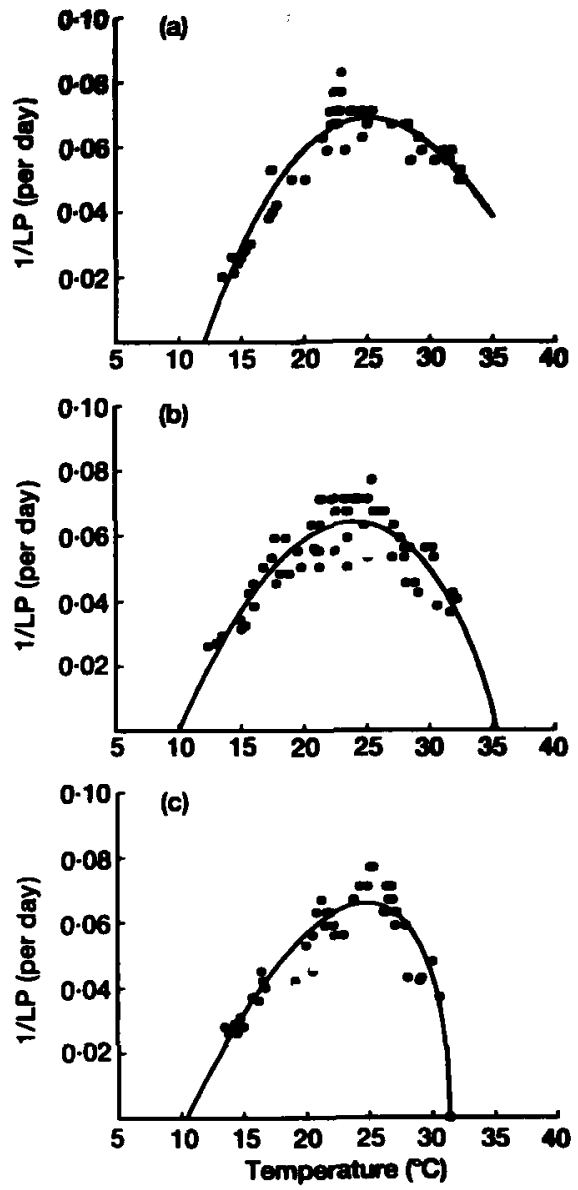

Fig. 2. Relationships between the reciprocal of the latent period (1/LP) and daily mean temperature for (a) Puccinia arachidis, (b) Phaeoisariopsis persanata and (c) Cercospora arachidicola on groundnut. The fitted curves are given by equation 1 and the parameter values are shown in Table 1 .

This equation gives a parabolic curve when $\beta=I$ (that is when $T_{\text {ope }}$ is midway between $T$. and $\left.T_{\max }\right)$. The response of biological systems to temperature is often asymmetric, with $T_{\text {on }}$ cloeer to $T_{\max }$ than to $T_{\text {min. }}$. Here $\beta$ is less than 1 for both leaf spot diseases and the asymmetry is most clear for early leaf spot (Fig. 2c).

Parameter values for rust, late leaf spot and early leaf spot were obtained using the Simplax method for non-linear least squares estimates (Table 1). The data provide flirty sood extionates (small standard error) of $T_{\text {in }}$ and $T_{\text {m }}$ for ol three diseases. The estimates of $T$ ma are bos certain, eppecillty for rust where comeiterabl extrapolation would be necens for I/Rs is 
Table 1. Parameter values obtained by fitting equation 1 to data relating the reciprocal of latent period (1/LP) to temperature for three diseases of groundnut (cv. TMV 2)

\begin{tabular}{lccccc}
\hline Pathogen & $\begin{array}{c}T_{\text {min }} \\
\left({ }^{\circ} \mathrm{C}\right)\end{array}$ & $\begin{array}{c}T_{\text {opt }} \\
\left({ }^{\circ} \mathrm{C}\right)\end{array}$ & $\begin{array}{c}T_{\max } \\
\left({ }^{\circ} \mathrm{C}\right)\end{array}$ & $\begin{array}{c}y_{\max } \\
\text { (per day) }\end{array}$ & $r^{2}$ \\
\hline Puccinia arachidis & $12 \cdot 1 \pm 0.4$ & $25.2 \pm 0.4$ & $39.8 \pm 3.3$ & 0.070 & 0.90 \\
Phaeoisariopsis personata & $10.0 \pm 0.7$ & $23.9 \pm 0.4$ & $35.3 \pm 1.6$ & 0.064 & 0.75 \\
Cercospara arachidicala & $10.4 \pm 0.6$ & $24.8 \pm 0.4$ & $31.4 \pm 0.5$ & 0.066 & 0.83 \\
$P$. personata & $10.2 \pm 0.5$ & $23.9 \pm 0.4$ & $33.0 \pm 0.7$ & 0.068 & 0.87 \\
\hline
\end{tabular}

$T_{\min }=$ minimum temperature.

$T_{\text {opt }}=$ optimum temperature.

$T_{\max }=$ maximum temperature.

$y_{\max }=$ maximum value of $\mathrm{l} / \mathrm{LP}$ at $T_{\mathrm{opt}}$

$r^{2}=$ coefficient of determination (corrected).

a Using data only from controlled environment.

approach zero. The difference between $T_{\max }$ for rust and late leaf spot is not statistically significant. In practice it was not possible to maintain potted groundnut plants at daily mean temperatures above $33^{\circ} \mathrm{C}$. We are confident in the value of $T_{\max }$ for early leaf spot, since we found that sporulation did not occur with a daily mean temperature of $31.4^{\circ} \mathrm{C}$ before leaf senescence after about 40 days. This result is shown as $I / L P=0$ in Fig. $2 c$, but it was not included in the curve-fitting procedure.

The pattern of response in Fig. 2 is consistent with other reports of the effect of temperature on latent period. Taking rust as an example (Fig. 2a), the relationship between $1 / L P$ and temperature is linear between $12^{\circ} \mathrm{C}$ and $22^{\circ} \mathrm{C}$. Therefore, over this temperature range, the relationship between latent period and temperature is hyperbolic and is the same shape as that described for Puccinia hordei on barley by Beresford \& Royle (1988).

Between $12^{\circ} \mathrm{C}$ and $28^{\circ} \mathrm{C}$ the relationship is distinctly non-linear, and has a similar form to those found for Pyrenophora teres on barley and Mycosphaerella graminicola on spring wheat by Shaw (1986, 1990). Comparing latent periods at $25^{\circ} \mathrm{C}$ and above $30^{\circ} \mathrm{C}$, our data also confirm the observation by Kochman \& Brown (1975), with Puccinia coronata f.sp. avenae on oats, that the latent period increases at high temperatures. The overall pattern of response of latent period to a wide temperature range agrees with that for $P$. recondita on wheat shown by Eversmeyer et al. (1980). They also found skewed temperature developmental curves for latent period with $T_{\min }=10^{\circ} \mathrm{C}, \quad T_{\text {opt }}=26.5^{\circ} \mathrm{C}$ and $T_{\max }=32.2^{\circ} \mathrm{C}$ which would be described satisfactorily by equation 1.

The latent period values for $P$. arachidis on groundnut presented here agree with those found by Savary (1985) for the same disease in West Africa. It should be noted however that latent period also varies with the groundnut genotype (Foster et al., 1980; Johnson et al., 1986; Nevill, 1981; Savary, 1987; Savary \& Zadoks, $1989 \mathrm{a}, \mathrm{b})$, with longer periods associated with resistance to the disease. We used a highly susceptible genotype (TMV 2) with a short latent period. Savary (1987) also noted a slight increase ( 0.3 days) in latent period for rust with the developmental stage of groundnut and a larger increase (0.3-2.2 days) with leaf age. Our observations were confined to 4 -week-old plants and leaves 3-5.

Values of $T_{\text {opt }}$ for the three groundnut diseases in this study were all close to $25 \mathrm{C}$. but there were larger differences in $T_{\min }$ and especially $T_{\max }$. The fitted value of $T_{\min }$ was about $2 \mathrm{~K}$ greater for rust than either of the leaf spot diseases (Table 1), but this may partly be due to an artefact of the fitted curve since there are no data points for $1 / L P<0.02$ (Fig. 2a). Differences between the diseases are nearer to $1 \mathrm{~K}$ at $1 / \mathrm{LP}=0.03$ (about the minimum for leaf spot diseases). There are much larger differences in the fitted values of $T_{\text {max }}$ (Table 1), but at high temperatures there are very few data points for 1 LP $<0.04$. As stated earlier, we have most confidence in the $T_{\max }$ value for early leaf spot. Even at $1 / L P=0.05$ (without extrapolation) however the upper temperature value for rust is at least $3 \mathrm{~K}$ greater than for the 
leaf-spot diseases (Fig. 2). We suspect that the fitted value of $T_{\max }$ for rust is unrealistically large, since we know that the upper limit for urediniospore germination is about $34 \mathrm{C}$ (Butler \& Jadhav, 1991).

Nevill (1981) observed latent periods of $14 \cdot 6$ days for $P$. personata and 21.7 days for $C$. arachidicola at $25 \mathrm{C}$ on detached leaves of groundnut $\mathrm{cv}$. TMV 2. In the present study the value for $\boldsymbol{P}$. personata agrees with this observation, but for $C$. arachidicola a latent period of 15 days was observed. Foster et al.(1980) noted that sporulation of $C$. arachidicola was delayed by 3 days with detached leaves of groundnut compared with intact leaves, and this could partly explain the discrepancy. Shew et al. (1988) stated that late leaf spot severity can be expected to be highest when temperatures near $24 \mathrm{C}$ occur during long leaf wetness periods, and at a constant temperature of $32 \mathrm{C}$ they found complete inhibition of infection and development. This happened with six different genotypes. These observations agree reasonably well with our results. where $T_{\text {opt }}$ was $23.9 \mathrm{C}$, although our fitted value for $T_{\max }$ was $35 \cdot 3 \mathrm{C}$ for late leaf spot.

Since rust and late leaf spot commonly occur together on groundnut (Subrahmanyam et al., 1992) it would be relevant to know if the latent period is affected by mixed infection on the same leaf. The experiments reported here did not examine this, but we have carried out mixed inoculations with all three pathogens elsewhere. We could not detect any difference in the latent period between inoculations with single and multiple pathogens.

\section{Daily versus hourly temperatures}

The data presented in Figs 1 and 2 were obtained both from controlled environments and from the field. In controlled environments, the difference between day and night temperatures varied from 2 to $11 \mathrm{~K}$, and the maximum temperature was $30 \mathrm{C}$. In the field the daily range of temperature commonly exceeded $20 \mathrm{~K}$ and the maximum temperature reached $43 \mathrm{C}$ on occasions. The results for late leaf spot will be examined in more detail.

In Fig. 3 data from the field (open points) and controlled environments (closed points) are distinguished, and we re-fitted equation I using only controlled environment data. This increised $v_{\text {mas }}$ and reduced $T_{\text {max }}$ (Tilble 1 ) and the majority of points from the field lie below the Cl: curve.



Fig. 3. The relationship between the reciprocal of the latent period (1/LP) and daily mean temperature for Phaeoisariopsis personata on groundnut. Data from controlled environment and field experiments are distinguished by closed and open circles respectively. The curve given by equation 1 was fitted using only closed circles with the parameter values for controlled environments in Table 1

The field data can be used to test the validity of equation 1 with parameter values from controlled environments (Table 1), since they are an independent data set. If equation 1 is used to calculate daily developmental increments (1/LP) from daily mean temperatures between the time of inoculation and the end of the latent period. the sum of the daily developmental increments $(D)$ would be expected to reach unity at the end of the latent period:

$$
D=\sum_{d a y=1}^{L P} \frac{1}{L P}
$$

Similarly, hourly developmental increments can be calculated from equation 1 by assuming that the value of $1 / L P$ over the period of $1 \mathrm{~h}$ (units per $h$ ) is the daily increment divided by 24 .

The field data were analysed by calculating hourly developmental increments from mean hourly air temperature (with $y_{\max }=0.068$ per $24 \mathrm{~h}$ ) from the time of inoculation to the observed end of the latent period. Temperatures from the dew chamber and growth cabinet were used during the infection phase. and temperatures from the automatic weather station were used when plants were in the field. The sum of the hourly increments. $D$ (equation 2) was assessed for each experimental period. In this proceduri, no development was assumed when the air temperature was greater than or equal to $T_{\text {max }}$.

Values of $D$ for each experiment are given in Table 2 . In all but two cases. $D$ was less than one and the overall mean was 0.86 . This indicates that the developmental rate from equation I using 
Table 2. Accumulated development estimated from hourly mean temperature during the observed latent periods in field experiments. Data are for late leaf spot using equations $I$ and 2 with parameters determined from daily mean temperatures in controlled environment experiments

\begin{tabular}{|c|c|c|}
\hline $\begin{array}{l}\text { Observed } \\
\text { latent period } \\
\text { (days) }\end{array}$ & $\begin{array}{c}\text { Mean } \\
\text { temperature } \\
\left({ }^{\circ} \mathrm{C}\right)\end{array}$ & $\begin{array}{l}\text { Accumulated } \\
\text { development }\end{array}$ \\
\hline $20 \cdot 0$ & 19.8 & 1.01 \\
\hline 18.0 & $20 \cdot 8$ & 0.87 \\
\hline 20.0 & $21 \cdot 2$ & 0.93 \\
\hline 20.0 & 23.4 & 0.97 \\
\hline 17.0 & 23.4 & 0.85 \\
\hline $19-0$ & $25 \cdot 1$ & 0.93 \\
\hline 19.0 & $27-0$ & 0.88 \\
\hline $19 \cdot 0$ & 27.9 & 0.84 \\
\hline $22 \cdot 0$ & $28 \cdot 8$ & 0.93 \\
\hline $22 \cdot 0$ & $28 \cdot 1$ & 1.01 \\
\hline 17.0 & $27 \cdot 6$ & 0.84 \\
\hline 18.0 & $29 \cdot 3$ & 0.77 \\
\hline 19.0 & $30 \cdot 3$ & 0.76 \\
\hline 18.0 & $30 \cdot 2$ & 0.75 \\
\hline $24 \cdot 0$ & 31.8 & 0.82 \\
\hline 25.0 & $32 \cdot 1$ & 0.81 \\
\hline 25.0 & $31 \cdot 8$ & 0.84 \\
\hline 18.0 & $21 \cdot 2$ & 0.78 \\
\hline $18-0$ & $22-4$ & 0.89 \\
\hline 15.0 & $22 \cdot 5$ & 0.82 \\
\hline $15 \cdot 0$ & 23.6 & 0.83 \\
\hline 14.0 & $24 \cdot 3$ & 0.82 \\
\hline 14.0 & $25 \cdot 1$ & 0.84 \\
\hline
\end{tabular}

hourly values is $16 \%$ too small. We therefore questioned if the value of $y_{\text {max }}$ in equation 1 would be greater if the temperature was constant throughout the experimental period. For plants maintained at $24 \mathrm{C}\left(T_{\text {opt }}\right)$, the time to reach $50 \%$ sporulation was 13 days (Fig. 4), giving $y_{\max }=0.077$ per day $(14 \%$ greater than 0.068 per day for the controlled environment curve).

Using a value of $y_{\max }=0.077$ per $24 \mathrm{~h}$, latent periods predicted from hourly developmental increments (equation 2) are in overall agreement with observed values (Fig. 5). Estimates from equations 1 and 2 using daily mean temperatures (with $y_{\max }=0.068$ per day) agree well with observed latent period when the mean temperature is close to $T_{\text {opt }}$ (small latent period values), but tend to be less than observed latent period at intermediate temperatures and much greater when the mean temperature is close to $T_{\max }$ (observed latent period $>24$ days in Fig. 5).

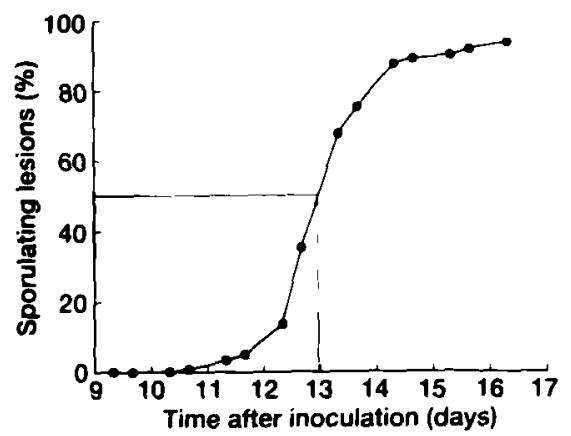

Fig. 4. Change in number of sporulating lesions with time for Phaeoisariopsis personata on groundnut maintained at a constant temperature of $24 \mathrm{C}$. The time of $50 \%$ sporulation ( 12.9 days) is indicated.

We consider that the temperature response curve in equation 1 provides good biological insight into the relationships between latent period and temperature. The rate of pathogen development would be expected to respond to temperature in a similar way to processes such as spore germination or infection. This appears to be the case, comparing the curves in Fig. 2 to other temperature response curves (see for example Figs 3 and 4 in Butler \& Jadhav, 1991). The form of the response curve became clear only when a wide range of temperatures were included in the experiments.

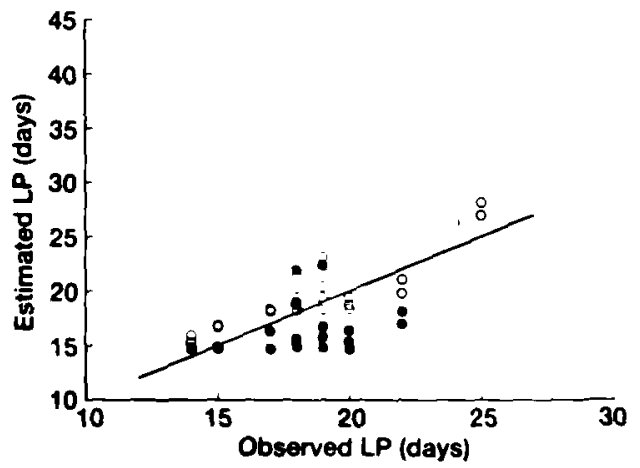

Fig. 5. Comparison between latent periods for late leaf spot, observed in the field and cstimated from Equations 1 and 2 using daily mean (closed circles) and hourly mean (open circles) temperatures. The value of $y_{\max }$ in Equation 1 was 0.068 per day for daily mean temperatures and 0.077 per $24 \mathrm{~h}$ for hourly mean temperatures. Other parameter values are those for controlled environments in Table I 
Limitations to the use of daily mean temperature to calculate latent period become apparent when the temperature range is in the non-linear part of the response curve and when the temperature during part of the day exceeds $T_{\max }$. The analysis shows a marked improvement in the simulation of latent periods using mean hourly temperatures, provided the developmental rate determined at a constant temperature is used.

\section{ACKNOWLEDGEMENTS}

Journal Article No. 1400 of the International Crops Research Institute for the Semi-Arid Tropics (ICRISAT).

\section{REFERENCES}

Beresford RM, Royle DJ, 1988. Relationships between leaf emergence and latent period for leaf rust (Puccinia hordei) on spring barley, and their significance for disease monitoring. Journal of Plant Disease and Protection 95, 361-71

Broughton WJ, Dilworth MJ, 1971. Control of leghaemoglobin synthesis in snake beans. Biochemistry Journal 25, 1075-80

Bunting AH, Gibbons RW, Wynne JC, 1985. Groundnut (Arachis hypogaea L.). In: Summerfield RJ, Roberts EH, eds. Grain Legume Crops. London, UK: Collins, 747-800.

Butler DR, 1990. Weather requirements for infection by late leaf spot in groundnut. In: Hildebrand GL, Schmidt G, Singh L. Subrahmanyam P, Wightman JA, eds. Proceedings of the Fourth Regional Groundnut Workshop for Southern Africa. 19-23 March 1990. Patancheru, India: ICRISAT, 99-104.

Butler DR, Jadhav DR, 1991. Requirements of leaf wetness and temperature for infection of groundnut by rust. Plant Pathology 40. 395-400.

Clifford BC, 1973. The construction and operation of a dew-simulation chamber. Nen Phytologist 77 , 619. 23

Cook $M, 1980$. Host parasite relations in uredial infections of peanut by Puccinia arachidis. Phytopatholog. 70, 822-6.

Eversmeyer MG, Kramer CL. Browder LE, 1980. Effect of temperature and host : parasite combination on the latent period of Puccinia recondita in seedling wheat plants. Phytopathology 70, 938-41.

Foster DJ, Beute MK. Wynne JC, 1980. Spore production and latent period as mechanisms of resistance to Cercospora arachidicola in four peanut genotypes. Peanut Science 7, 88-90.

Johnson DA, 1980. Effect of low temperature on the latent period of slow and fast rustıng winter wheat genotypes. Plant Disease 64, 1006-8.

Johnson CS, Beute MK, Ricker MD, 1986. Relationship between components of resistance and disease progress of early leaf spot on Virginia-type peanut. Phytopatholog.' 76, 4959.
Knudsen GR, Spurr Jr HW, Johnson CS, 1987. A computer simulation model for Cercospora leaf spot of peanut. Phylopalhology 77, 1118-21.

Kochman JK, Brown JF, 1975. Host and environmental effects on post-penetration development of Puccinia graminis avenae and $P$. coronata avenae. Annals of Applied Biology 81, 33-41.

Lannou C, Blizoua Bi P, 1989. Conditions for the development of $C$. personatum leaf lesions on groundnut after artificial infection. Oléagineux 44, 531-5.

Malliah KV, Rao AS 1979. Groundnut rust: factors infuencing disease development, sporulation and germination of uredospores. Indian Phytopathology 32, 382-8.

McDonald D, Subrahmanyam P, Gibbons RW, Smith DH, 1985. Early and Late Leaf Spots of Groundnut. Patancheru, India: ICRISAT Information Bulletin No. 21.

Nevill DJ, 1980. Studies of resistance to foliar pathogens. In: Gibbons RW, ed. Proceedings of the International Workshop on Groundnut. 13-17 October 1980. Patancheru, India: ICRISAT, 199-202.

Nevill DJ, 1981. Components of resistance to Cercospora arachidicola and Cercosporidium personatum in groundnut. Annals of Applied Biology 99, 77-88.

Reed KL, Hamerly ER, Dinger RF, Jarvis PG, 1976. An analytical model for field measurements of photosynthesis. Journal of .4pplied Ecology 13,925-42.

Savary S, 1985. Effets du niveau de contamination et de la temperature sur quelques etapes du cycle de Puccinia arachidis Speg. Agronomie 5, 479-85.

Savary $S, 1987$. Decrease by plant development and leaf age of susceptibility of groundnut to rust (Puccinia arachidis) in a susceptible cultivar. Netherlands Jowrnal of Plant Pathology 93, 25-31.

Savary S, Zadoks JC, 1989a. Analyse des composantes de l'interaction hòte-parasite chez la rouille de l'arachide. I. Definition et mesure des composantes de résistance. [Analysis of host parasite interaction components in groundnut rust. I. Definition and measurement of resistance components.] Oléagineux 44, 163-74.

Savary S, Zadoks JC, 1989b. Analyse des composantes de l'ınteraction hóte-parasite chez la rouille de l'arachide. II. Mesure de la résıstance intermédiaire par la essai en micro-parcelles. [Analysis of host parasite interaction components in groundnut rust. II. Measurement of intermediate resistance using a micro-plot trial.] Oléaginenx 44, 215-24.

Shaw MW, 1986. Effects of temperature and leaf wetness on Pyrenophora teres growning on barky cr. Sonja. Plani Pathology 35, 294 - 309.

Shaw MW, 1990 Effects of temperalure. leaf wetness and cultivar on the latent period of Micosphoerella gruminicola on winter wheat. Plant Pathologv 39. 25568 .

Shew BB, Beute MK. Wynne JC, 1988. Effects of temperature and relative humdity on expression of resistance to Cercasporidinur prisomurum in peanut. Phyropalholog!' 74, 443-8. 
Smith DH, 1980. Groundnut foliar diseases in the United States. In: Gibbons RW, ed. Proceedings of the International Workshop on Groundnut. 13-17 October, 1980. Patancheru, India: ICRISAT, 18692.

Subrahmanyam P. McDonald D, 1983. Rust Disease of Groundnut. Patancheru, India: ICRISAT Information Bulletin No. 13.

Subrahmanyam P, Wongkaew S, Reddy DVR, Demski JW, McDonald D, Sharma SB, Smith DH, 1992. Field Diagnosis of Groundnut Diseases. Patancheru, India: ICRISAT Information Bulletin No. 36.

Teng PS, Blackie MJ, Close RC, 1980. Simulation of the barley leaf rust epidemic: structure and validation of BARSIM-1. Agricultural Systems 5, 55-73.

Tomerlin JR, Eversmeyer MG, Kramer CL, Browder LE, 1983. Temperature and host effects on latent and infectious periods and on urediniospore production of Puccinia recondita f.sp. tritici. Phytopathology 73, 4I4-19.

Wynne JC, Beute MK, Nigam SN, 1991. Breeding for disease resistance in peanut (Arachis hypogaea L.). Annual Revien of Phytopathology 29, 279-303.

Zadoks JC, 1972 Methodology of epidemiological research. Annual Review of Phytopathology 10, 253-76. 
This document is a scanned copy of a printed document. No warranty is given about the accuracy of the copy. Users should refer to the original published version of the material. 